\title{
AZAROSO MILOUD
}

\author{
Cuento original de \\ Souad Hadj-Ali Mouhoub
}

El ojo seguía rodando por los túneles del metro en busca de su dueño, pero ni rastro. Estaba claro que no iba a encontrarle en ningún recoveco de esos sombríos y húmedos laberintos donde solo pueden albergarse las ratas y los bichos, pero le extrañaba que no le hubiera buscado durante todo ese tiempo. Está demostrado que se puede vivir con un solo ojo, incluso sin ninguno, pero pudiendo tener los dos... Y su dueño, ¿sabía de su supervivencia? ¿Se habría imaginado que seguiría allí, intacto? Si no volvió nunca era porque habría supuesto que su ojo había reventado aquel mismo día del accidente, aplastado por las ruedas del tren contra los raíles. Lo que más lamentaba el ojo era permanecer allí tirado mientras su dueño usaba uno de cristal. También le dolía no poder servirle a nadie cuando todavía conservaba todo su brillo y su vigor. No sabía cómo hacerse ver. Tendría que tomar carrerilla y con el máximo impulso, saltar al andén, evitar que lo pisasen y abordar a quien pudiera atenderle, comprender su intención y llevarle a algún hospital donde lo conservarían para un implante. ¿Pero cómo iba a emprender esa misión que sabía de antemano que sería un fracaso rotundo? Por otra parte, le preocupaba que alguna rata o algún gato callejero le confundieran con una cucaracha y se lo comieran, por eso no paraba de rodar dándose por misión buscar a Miloud.

Miloud erraba por la ciudad; andaba como alma en pena, sin rumbo. Solo caminaba, como en busca de algo, ¿su ojo? ¿Acaso se daba cuenta de que le faltaba uno? total, para ver lo que le rodeaba era mejor no tener más que uno, con dos habría visto el doble de miseria.

El ojo: "A ver si ya no me necesita y no quiere saber nada de mí...”

Miloud: "En qué mierda estoy metido; ay, si pudiera quedarme ciego...” El ojo: "Ah, si pudiera saltar al andén..."

Miloud: "Ojalá me hubiera matado aquel tren..." 
El ojo: "Pero, ¿y si salto y me aplastan?"

Miloud: "Habría dejado de sufrir..."

El ojo: "Tal vez él esté allí y me vea..."

Miloud: "Con una pierna que me falta, el pie que me duele..."

El ojo: "me coja y me coloque en mi sitio"

Miloud: “QQué dolor de cabeza!”

Y seguía cojeando plantado sobre una pierna de plástico que amenazaba con romperse, y arrastrando su talón aún ensangrentado que nunca cicatrizó.

Cuando se despertó, gritó de dolor. Le dolían los dedos del pie, el tobillo, la rodilla de la pierna amputada. Quería rascarse la planta del pie que los cirujanos habían separado del resto del miembro, sentía hormigueo y pesadez en la pantorrilla inexistente. Y como no podía moverse por el efecto de la anestesia, lloraba sin saber siquiera dónde se encontraba reclamando a todos sus santos y antepasados por si tuvieran piedad y le salvaran de su calvario.

En su delirio, Miloud corría hacia la muchacha que un hombre maltrataba en el andén. Temía que la tirase al vacío, por donde pasaría en cualquier momento el metro. En su delirio, le gritaba al hombre aquél que la dejase, que no le hiciera daño mientras agarraba a la chica y la atraía hacia sí.

En su cólera ese hombre rabioso le fustigaba con la mirada. En su cólera rugía y se interponía entre ambos. Con un gesto de extrema brutalidad, tiró a Miloud al vacío unos segundos antes de que pitara el tren anunciando su entrada en a la estación. En su fugacidad, el tren atropelló a Miloud.

Y Miloud gritó de dolor. Desde su delirio veía cómo agonizaba su pierna derecha pegada al segmento de hierro de la vía, discernía los trozos de carne y hueso de su talón izquierdo esparcidos en el suelo y buscaba con un ojo al ojo hermano caído de su órbita.

Al día siguiente a su accidente, Miloud salió del anonimato. Ya no era aquel chico sin papeles que dormía en un coche abandonado en una de las callejuelas cercanas a la plaza de Castilla; el chico que huía de su sombra para que no le dilatara y que solo salía de noche como los topos en busca 
de algún resto de comida. La única vez que se atrevió a mostrar su cara al día vio lo que sus ojos y su hombría no admitían: un hombre violentaba a una mujer en el andén del metro de Embajadores, un domingo a media tarde, a la hora en que la gente se encontraba reunida en sus casas o en los restaurantes para romper la rutina de una semana laboral. Miloud no entendía nada de lo que profería el hombre a la mujer, los pocos meses que llevaba en Madrid, escondido en su cobijo solitario no le permitían comprender el idioma, pero la violencia no necesita intérpretes, la violencia se hace entender y Miloud lo captó todo, por eso se sintió interpelado. El "nif" no le permitía permanecer inmóvil e indiferente, tenía que ayudar a esa mujer. Intervino sin pensar en nada que pudiera perjudicarle en su situación de clandestino. ¿Papeles, irregular...? Nada, no pensó en nada y se abalanzó sobre la mujer para sacarla de las garras de su predador, pero ése, aún más furioso, separó a Miloud de la mujer y le tiró al vacío justo cuando pitaba el tren anunciando su llegada. El conductor que no sospechaba de nada no pudo impedir que la máquina devorara una parte del cuerpo de Miloud. Aplastada y arrinconada, la víctima sintió el crujir de su pierna bajo las ruedas, el chorro hirviente de su sangre y el vacío que dejó su ojo cuando saltó de la concavidad donde anidaba.

Al día siguiente al accidente, todo Madrid conocía a Miloud, aquel chico valiente que salvó a una mujer de las manos de un hombre violento que quería matarla en el metro. Todos los periódicos divulgaron la noticia y las cámaras, ávidas, se preparaban para dar un rostro a aquel ilustre desconocido que pronto sería el héroe a quien el alcalde iba a decorar con la medalla de oro de la valentía y a quien la Comunidad de Madrid iba a otorgar un permiso de residencia como testimonio de su reconocimiento por tan noble acción.

Miloud se convirtió en poco tiempo en la estrella del hospital i2 de octubre y de la capital de España. Cuando se repuso de su accidente fue el invitado de muchos responsables locales y hasta se benefició de una casa y una pensión. La celebridad ahogó a Miloud que no estaba acostumbrado a tanto protagonismo. Pero cuando los focos de las cámaras se apagaron, él ya no sabía quién era y empezó a esconderse bajo las camas de su casa para no ver a nadie y que nadie le viera una cara atrofiada y asimétrica,

1 Palabra árabe que significa nariz y simboliza la dignidad en la cultura argelina. 
con un ojo lloriqueando y el otro ausente. Se escondía para no deambular claudicando, sin saber manejar las muletas que pretendían sustituir la pierna perdida. Con el tiempo Miloud no era más que un nombre, extranjero, que algunos recordaban remotamente... "¿no es el chico del metro que...?”. "Sí es él”; “¿qué será de él? pobre muchacho”. Y enseguida se hablaba de otra cosa porque Miloud solo era una entre tantas otras.

El ojo que seguía rodando por los interminables túneles del metro en busca de su dueño, logró su carrerilla para saltar al andén, pero, ay de él, cuando por fin lo consiguió con la esperanza de que alguien se apiadara de él y le ayudara a buscar a Miloud o le llevara a algún hospital para que sirviera de ojo postizo, pasó la máquina de la limpieza y lo aspiró, así sin más, haciéndolo explotar dentro de su vientre lleno de las inmundicias del metro, aquellas que tiran los viajeros y que se acumulan en los rincones. Desde entonces ya nadie pregunta por Miloud.

Madrid, 20 de mayo de 2008 